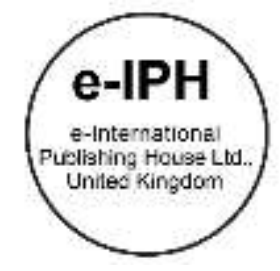

\title{
Preliminary Study on Sensory Design for Autism Centre
}

\author{
Roslinda Ghazali¹, Siti Rasidah Md. Sakip², Ismail Samsuddin² \\ 1 Department of Post-graduate, \\ 2 Faculty of Architecture, Planning \& Surveying, \\ Universiti Teknologi MARA Perak, Malaysia \\ lindakeruing@gmail.com, sitir704@perak.uitm.edu.my, ismai578@perak.uitm.edu.my \\ Tel:: 0060135185148
}

\begin{abstract}
Autism Spectrum Disorders (ASD) is a lifelong handicap that affects the lives and the people around them. Knowing them as a unique person, designated learning environment should consider the sensory issues to overcome their needs. However, designers are lack of awareness in terms of sensory design while designing learning spaces for autistic children. This research objective is to identify the sensory design of physical learning enviroment in the Autism Centre, while the paper aims to develop the Design Criteria Checklist of sensory design for Autism Centre. The result of the study highlighted factors that relating to quality physical learning environment.
\end{abstract}

Keywords: Autism; sensory design, physical learning environment; design criteria checklist;

eISSN: 2398-4287 @ 2018. The Authors. Published for AMER ABRA cE-Bs by e-International Publishing House, Ltd., UK. This is an open access article under the CC BYNC-ND license (http://creativecommons.org/licenses/by-nc-nd/4.0). Peer-review under responsibility of AMER (Association of Malaysian Environment-Behaviour Researchers), ABRA (Association of Behavioural Researchers on Asians) and cE-Bs (Centre for Environment-Behaviour Studies), Faculty of Architecture, Planning \& Surveying, Universiti Teknologi MARA, Malaysia.

DOI: https://doi.org/10.21834/e-bpj.v3i8.1392

\subsection{Introduction}

Autism Spectrum Disorder (ASD) has occurs in every nation of the world and it is a life-long impact to their affected relative (Samadi \& McConkey, 2011). ASD is a neurological disorder that affects a child's developmental disability causing social, communication and behavioral challenges (Yates, Mclaren, \& Proksch, 2016). In Malaysia, the Ministry of Health in 2004 reported that autism prevalence rates were 1 case for 600 births, with an estimated 13,333 children aged 15 and under are having autism in the country. However, the prevalence rate is closer to the rates in developed countries such as 1 case for 68 birth in the US and 1 case to 100 birth in the UK (Chiam, 2016). While the Social Welfare Department (Jabatan Kemajuan Masyarakat- JKM) statistics showed that 12,785 adults and autism children has registered with the organization (Hamzah, 2016). He reported that out of the total, 9,208 were those aged 18 and under and believed there are still many autisms yet to register. This is due to lack of awareness among the parents as well as staying away in the rural areas, parents do not know and do not understand about autism and also feel embarrassment led them to unable to enroll their children under the JKM, thus unable to enjoy the government's support. With the tremendous in numbers, it gives impact to the country, community and family. The increasing rate of ASD prevalence is also a great challenge for the education system and needs national efforts to address the problems (Matin, Haghgoo, Samadi, Rassafiani, Bakhshi, Hassanabadi, 2017). In addition, it became a significant challenge to public education because many children with autism required intensive interventions to facilitate their participation and success in the educational setting (Kinnealey, Pfeiffer, Miller, Roan, Shoener, Ellner, 2012).

In Malaysia, Non-Government Organization (NGO), private learning centres, and healthcare professionals has been recommended by the government to overcome the cases to equipped in treating and care for autistic individuals (Chiam, 2016). This is because autistic child can be developed independent living skills during the learning environment process. Cikili, Sari, \& Deniz (2015) mentioned that

eISSN: 2398-4287 @ 2018. The Authors. Published for AMER ABRA cE-Bs by e-International Publishing House, Ltd., UK. This is an open access article under the CC BYNC-ND license (http://creativecommons.org/licenses/by-nc-nd/4.0/). Peer-review under responsibility of AMER (Association of Malaysian Environment-Behaviour Researchers), ABRA (Association of Behavioural Researchers on Asians) and cE-Bs (Centre for Environment-Behaviour Studies), Faculty of Architecture, Planning \& Surveying, Universiti Teknologi MARA, Malaysia.

DOI: https://doi.org/10.21834/e-bpj.v3i8.1392 
no matter which learning environment they are in, education is defined as the process of behaviour changing. They suggested that autistic children are encouraged to continue their education in different learning environments due to their difficulty impairments in social, communication, and behavioural skills (Cikili et al., 2015; Shaari \& Ahmad, 2016). Autistic children develop skill, social interaction and develop their fullest potential while in school. Therefore, a quality and properly designed physical learning environment will enrich the development and education of children. Hence, Shaari and Ahmad suggested that ensuring the quality of school environment contributing to improve school readiness among children and a better education system.

Learning environment has become significance because research has proven that the quality of educational facilities affects learning outcomes and the individuals within the building (Nazri \& Ismail, 2016). In order to enhance the development of children with autism, they stressed that it is important to ensure that the building is effective, convenient and fit for everyone to use, especially for children with autism. Architects role and responsibility is to provide design that respond to the needs of all members of society. However, designers are lack of awareness of sensory issues regarding the built environment in the daily life of autism before designing stage. Any unwanted distraction can impact negatively upon that child's ability to learn (Mcnally, Morris, \& Mcallister, 2013) (The National Autistic Society, 2015). Once autistic children starting their learning process, the quality of the environment are so much important and avoid confusing and frustrating to the autistic mind (Beaver, 2011). This is because autism is an extremely complex condition which affects each person differently and can benefit more from the sensory input that the built environment provides (The National Autistic Society, 2015). This research objective is to identify the sensory design of physical learning enviroment in the Autism Centre, while the paper aims to develop the Design Criteria Checklist of sensory design for Autism Centre. Thus, it could be a significant contribution to technical agency and designers during their design stage for a better physical learning environment supported with sensory design features.

\subsection{Literature Review}

In this section, we elaborated about ASD and sensory processing and highlighted the impact of sensory design to autistic behaviour. Perhaps, this section would reviews related articles to gain better understanding on autism needs, physical learning environment and specifically on sensory design.

\subsection{Characteristic of ASD}

Individual with autism often affects a child's ability to communicate, understand language, play and relate to others (Boyce, Hunter, \& Howlett, 2003). They also identified that the symptoms as such repetitive activities, stereotyped movements, struggle to adapt in the environment and the daily routine and unusual responses to sensory experiences. Autism spectrum disorders (ASD) is characterized by social communication and social interaction (Yeo \& Teng, 2015). Researcher mentioned that ASD restricted repetitive patterns of behavior, interests and activities. Not only that ASD having poor in social especially poor eye contact, lack of joint attention, pedantic or odd speech patterns, lack of social problem-solving ability, lack of empathy, and difficulties interpreting body language. Children with ASD are having difficulties in developing their language skills, hearing and communicating. Therefore, they express themselves with exhibit unconventional behaviors such as being aggressive, bad temper or injuring themselves.

Children who diagnosed with autism have common symptoms and characteristics that affect school participation, including sensory processing difficulties, stereotyped behaviors, communication and language difficulties, low muscle tone, and sleep disturbances (Kinnealey, Pfeiffer, Miller, Roan, Shoener, Ellner, 2012). They may have difficulty engaging in typical occupations of childhood, such as activities of daily living, social participation, play, and education (Phillips, Minjarez, Mercier, Feinstein, \& Hardan, 2011).

\subsection{Autism Spectrum Disorder and Sensory Processing}

The term of Sensory processing refers to the method the nervous system in which the brain has trouble receiving and responding to information that comes in through the senses (Henshall, 2008; Phillips et al., 2011). Henshall added the sensory systems act as a route via which the brain receives information. The brain must then derive meaning from this information to develop and implement a response. Whereas, children and adult developing and process sensory information at a frequent basis without difficulties unlike person with autism. Researchers has been widely recognized and debate about people with ASD have unusual sensory experiences (Henshall, 2008). Henshall explained that these individuals may actively seek out or avoid sensory information, for example by putting their hands over their ears to block out sounds. In addition, children may have difficulties and engaging with others because of atypical sensory responses. Moreover, Phillips et al. (2011) also mentioned that behavioral and emotional problems have been associated with sensory processing differences and sensory symptoms have been significantly related to stereotyped interests and repetitive behaviors in ASD. Specifically, Henshall explained that sensitivity to sensory stimuli occurs along a variety, from hyper to hypo responsiveness. Hyperresponsiveness refers to the sensory channel being too 'open', and so there is too much stimulation for the brain to cope with, whereas hypo-responsiveness refers to the sensory channel not being open enough, therefore too little of the stimulation is able to get in and the brain is deprived of sensory input (Henshall, 2008) (Phillips et al., 2011). Researcher summaries the seven sensory systems which are within the nervous system: sound, touch, vision, taste, smell, movement, and body position. Table 1 shows a summary of these sensory systems and their functions.

Table 1. The Seven Sensory Systems

\begin{tabular}{ll}
\hline Vision & The faculty of seeing. \\
\hline Hearing & The faculty of perceiving sound. \\
\hline
\end{tabular}




\begin{tabular}{ll}
\hline Vestibular system & $\begin{array}{l}\text { Refers to structures within the inner ear that detect movement and changes in the } \\
\text { position of the head. }\end{array}$ \\
\hline $\begin{array}{l}\text { Vestibular system } \\
\text { Olfaction (the sense of smell) }\end{array}$ & Perceiving odours or scents. \\
\hline Gustation (the sense of taste) & $\begin{array}{l}\text { Perceiving the sensation of a soluble sensation caused in the mouth and throat by } \\
\text { contact Vith that substance. }\end{array}$ \\
\hline Tactile system & Perceiving touch, pressure, pain, temperature. \\
\hline Proprioceptive system & $\begin{array}{l}\text { Perceiving stimuli produced within an organism, especially relating to the position } \\
\text { and movement to the body. }\end{array}$ \\
\hline
\end{tabular}

\subsection{Physical Learning Environment}

The learning environment refers to the space allocated for classrooms, science labs, open spaces and offices (Amirul, Che Ahmad, Yahya, Lee Abdullah, Adnan and Mohamed Noh, 2013). They defined learning environment as the social context, psychological and pedagogical, which can affecting learning, achievement and attitudes of the students. Learning environment and features that are in it played a major role in improving learning in schools and is identified as major determinants of student learning. Learning environment capable of stimulating students to engage in the learning process and be able to influence the behavior of students as well as to assist in the development of their skills or cognitive perception.

Research done by Shaari \& Ahmad (2016) proved that there is a link between physical learning environment and children school readiness. Therefore, the importance of the physical learning environment can no longer be ignored. They suggested that a quality and properly-designed physical learning environment will boost the development and education of children as well as contributing to improved school readiness among children and a better education system. Hence, ensuring that school children are ready is important when designing a school. According to Fraser (1994) and Kilgour (2006), two major components of the learning environment were identified - physical component and psychosocial component. Physical component includes all physical aspects such as classrooms, teaching materials and learning facilities, both inside and outside the classroom. Psychosocial component related to the interaction that occurs between students and students, students with teachers and students with the environment. Both of these components complement each other in creating and shaping the learning environment and affect the learning processes that occur in it showed in figure 1. Since researcher based on architecture the interest would be focuses only the physical aspects such as school building and classrooms both inside and outside the classroom.

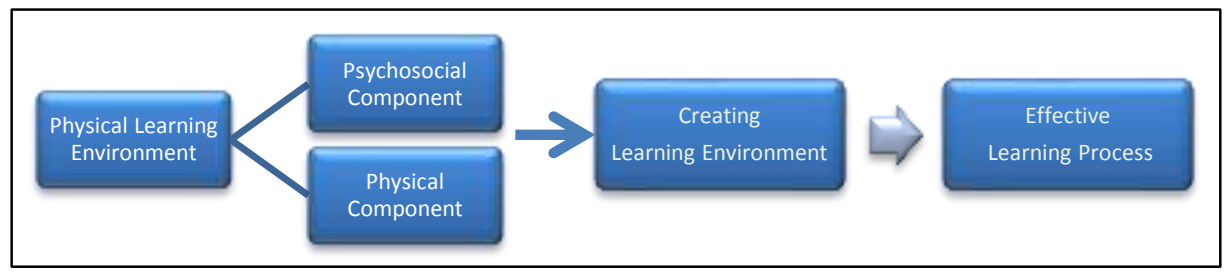

Fig. 1: Physical Learning Environment Flowchart

(Source: Ghazali, Md Sakip, \& Samsuddin, 2018)

\subsection{Sensory Design}

The environment gives a huge impact on a child with Sensory Sensitivity; also known as Sensory Processing Disorder or Sensory Integration Difficulty. Their senses can be either over-developed (hypersensitive) or under-developed (hyposensitive) which can result in feelings of anxiety, stress \& occasionally, physical pain. Both can have an impact on how a child handles different environments (Barker, 2014). Sensory design is design for living which how a space feels, sounds, looks, smells and functions can be incredibly affecting one or more of the seven senses which can have an overwhelming effect on their life (Society, 2015).

Research done by Paron-Wildes (2005) explained that when designing children's environments, it is important to consider the needs of children with neurological disorders and to think through the space as an experience. He explored with individuals suffering from problems with sensory integration or sensory defensiveness and revealed that autistic does not typically fall in the "normal" or "average" range of sensory values that are experienced. Therefore, an architect should consider designing spaces according to their sensory quality. This means grouping spaces into 'high-stimulus' and 'low-stimulus' areas with transition zones aiding the shift from one zone to the next (Society, 2015). It also mentioned that design spaces in a logical order based on use to support routine and predictability. The use one-way circulation so people can move between activities as seamlessly as possible with minimal distraction is important to autism. Escape place is to provide space for relief from the overstimulation of the environment. The space might be a small, partitioned area or crawl space in a quiet section of a room or building with the sensory environment neutral and customizable (Society, 2015). Observation by Goodyear (2014) described that two basic principles: the first is looking at autism as a sensory processing issue, and the second is defining architecture and design as the primary sources of the majority of sensory input in the built environment. Particularly, the sensory area isn't a place where students "get out of" doing their work but it is a place where students release energy or gain momentum so that they can focus on their work again.(Lingle, n.d.). As a matter of fact, there are many other sensory activities that can provide for autistic children if there is not enough space to set up a sensory area. For examples having a sensory box filled with tactile toys, make them run around the school, let them stack chairs, wipe tables, do jumping jacks next to their seat, or wipe the boards and even create an 
obstacle course in their classroom (Lingle, n.d.). Those activities are actually making a positive impact on their sensory needs, hence, improving their quality of life. When designing areas for children on the autism spectrum, it is important to have knowledge and understanding of how they experience the environment because it is also important to know that not all children are affected in the same way or to the same range. Whereas, many children are capable of learning within mainstream environments, some children require a more adapted and unique setting (Scott, 2009).

\subsection{The Impact of Sensory Design on Autistic Behaviour}

Autism is now widely recognised as a learning and communication difficult and they remained misunderstood and unable to communicate their difficulties (Beaver, n.d.). Children with challenging behaviour display their frustration in different ways and Beaver opined that when designing a building you don't know at the time that the occupants are going to be and even if you did, they would change as time went on. Hence, architect or designer should consider a building for autism, whether residential or educational, will not just be occupied by the children but also by their carers or teachers. Sensory Design Theory has been applied to countless fields to better understand and meet autistic needs (Mostafa, 2014). Due to the knowledge that fulfilment of individuals' needs is essential to designed physical learning environment to meet students' basic needs through acoustic, colour, smell, lighting, accessibility, wayfinding, compartmentation, scale of the building, quiet room, safety, garden and alternative (Mostafa, 2008; Vogel, 2008; Altenmüller-Lewis, 2017). We elaborate the impact of sensory design on autism and summarizes in Table 2.

Table 2. The Impact of Sensory Design on Autistic Behaviour

\begin{tabular}{|c|c|c|c|}
\hline Criteria & Avoid & Impact & Suggestion \\
\hline $\begin{array}{l}\text { Planning and Sense of Space } \\
\qquad \begin{array}{r}\text { (Beaver, n.d.). } \\
\text { (Beaver, 2011) }\end{array}\end{array}$ & $\begin{array}{l}\text { Complicated planning. } \\
\text { Crowded space }\end{array}$ & $\begin{array}{l}\text { Forced them too close together } \\
\text { Stress \& anxiety. }\end{array}$ & $\begin{array}{l}\text { Curved walls to give a sense of } \\
\text { friendliness. } \\
\text { Enough room without having too } \\
\text { closely in contact with each other. }\end{array}$ \\
\hline $\begin{array}{l}\text { Compartmentation } \\
\qquad \text { (Mostafa, 2014) }\end{array}$ & $\begin{array}{l}\text { Compartments need not be harsh and } \\
\text { strict }\end{array}$ & $\begin{array}{l}\text { Sensory cues such as ambiguity } \\
\text { and uncertainty. }\end{array}$ & $\begin{array}{l}\text { Through furniture arrangement, } \\
\text { difference in floor covering, difference } \\
\text { in level or even through variances in } \\
\text { lighting. }\end{array}$ \\
\hline $\begin{array}{l}\text { Building Scale } \\
\qquad \text { (Mcnally et al., 2013) }\end{array}$ & $\begin{array}{l}\text { Large school with many doors, windows, } \\
\text { staircases and the variety of classrooms, } \\
\text { corridors, offices and countless other } \\
\text { rooms. }\end{array}$ & $\begin{array}{l}\text { Disorienting, frightening, scary, } \\
\text { daunting and overwhelming. }\end{array}$ & $\begin{array}{l}\text { Small-scale schools or those with } \\
\text { simple building layouts, }\end{array}$ \\
\hline $\begin{array}{l}\text { Safety and Security } \\
\text { (Vogel, 2008) } \\
\text { (Arnaiz et al., 2011) }\end{array}$ & $\begin{array}{l}\text { Physical hazards (wiring, open } \\
\text { stairways, unscreened windows, loose } \\
\text { flooring, toxic paints, etc.) and emotional } \\
\text { safety and security. }\end{array}$ & $\begin{array}{l}\text { Prone to seizures and behaviours } \\
\text { like tantrums or "stimming," where } \\
\text { injury to self and others. }\end{array}$ & $\begin{array}{l}\text { Particularly, bathroom equipment, } \\
\text { lighting fixtures and mechanisms, } \\
\text { hardware, banisters, wall and floor tiles } \\
\text { must be well anchored. }\end{array}$ \\
\hline $\begin{array}{l}\text { Wayfinding } \\
\qquad \text { (Mcnally et al., 2013) }\end{array}$ & $\begin{array}{l}\text { Complex layouts, long corridors and } \\
\text { frequent changes of level }\end{array}$ & $\begin{array}{l}\text { Becoming disorientated or lost } \\
\text { causing stress. } \\
\text { Create a sense of anxiety. }\end{array}$ & $\begin{array}{l}\text { To ensure that circulation around the } \\
\text { school is as clear and comprehensible } \\
\text { as possible. }\end{array}$ \\
\hline $\begin{array}{l}\text { Accessibility } \\
\text { (Mcnally et al., 2013) }\end{array}$ & Complicated planning. & $\begin{array}{l}\text { Entering school environment from } \\
\text { the comfort of home moving to the } \\
\text { hustle and bustle of the school } \\
\text { environment can be distressing. }\end{array}$ & $\begin{array}{l}\text { To make this transition as } \\
\text { straightforward and as stress- free as } \\
\text { possible. }\end{array}$ \\
\hline $\begin{array}{r}\text { (Mcnally et al., 2013) } \\
\text { (Mostafa, 2014) }\end{array}$ & Over- stimulation environment & $\begin{array}{l}\text { Disrupting behaviour when they } \\
\text { become tired and distressed or } \\
\text { over- stimulated. }\end{array}$ & $\begin{array}{l}\text { A small partitioned area or crawl space } \\
\text { in a quiet section of a room, or } \\
\text { throughout a building in the form of } \\
\text { quiet corners. } \\
\text { To provide a neutral sensory } \\
\text { environment with minimal stimulation } \\
\text { that can be customized by the user to } \\
\text { provide the necessary sensory input. }\end{array}$ \\
\hline $\begin{array}{r}\text { Acoustic } \\
\text { (Mostafa, 2014) } \\
\text { (Nazri \& Ismail, 2016) } \\
\text { (Altenmüller-Lewis, 2017) } \\
\text { (Beaver, n.d.) }\end{array}$ & Noisy space. & $\begin{array}{l}\text { Afraid of noise. } \\
\text { The repetitive behaviour usually } \\
\text { exhibit dealing with this problem due } \\
\text { to their chronically high level of } \\
\text { stimulation }\end{array}$ & $\begin{array}{l}\text { To accommodate with proper } \\
\text { mechanism \& soundproofing such as } \\
\text { acoustic ceiling and a cleanable carpet. } \\
\text { To provide a quiet environment }\end{array}$ \\
\hline $\begin{array}{r}\text { Colour (Nazri \& Ismail, 2016) } \\
\text { (Altenmüller-Lewis, 2017) }\end{array}$ & Disturbing and overly stimulating colours. & Distress and anxiety & $\begin{array}{l}\text { Neutral, calming colours and the use of } \\
\text { natural materials. }\end{array}$ \\
\hline $\begin{array}{l}\text { Smell } \\
\qquad \begin{array}{r}\text { (Woronko \& Killoran, 2011) } \\
\text { (Mcnally et al., 2013) }\end{array}\end{array}$ & Strong smells. & $\begin{array}{l}\text { Distressing with odour over- } \\
\text { responsiveness }\end{array}$ & $\begin{array}{l}\text { The classrooms should scent-free } \\
\text { environments. }\end{array}$ \\
\hline $\begin{array}{r}\text { Lighting } \\
\text { (Altenmüller-Lewis, 2017) } \\
\text { (Mcnally et al., 2013) } \\
\text { (Kinnealey et al., 2012) }\end{array}$ & $\begin{array}{l}\text { Flickering light, reflections, glare from } \\
\text { direct sunlight (solar glare) and shadow } \\
\text { patterns of interior spaces. }\end{array}$ & Distress and anxiety. & $\begin{array}{l}\text { Allocation of windows at both low and } \\
\text { high level in the classroom. } \\
\text { To use of high-quality lighting. }\end{array}$ \\
\hline
\end{tabular}




\subsection{Research Design}

The mixed method for this study was based on Creswell (2003) suggestion where survey would facilitate the study. The data collections involve at least three methods for triangulation - questionnaires, personal on-site observations and documentation. Pusat Permata Kurnia (PPK), has been chosen as a site study. It is located in Sentul Kuala Lumpur, non-urban area locations within the Klang Valley region in Malaysia. The selections of this centre because this is the only centre of Autism and pioneer under Malaysian government. Currently, there is no-any evaluation or measured by any parties to evaluate the effectiveness, convenient and fit for autism. Therefore, in this study the Design Criteria Checklist (DCC) has been developed as a tool of measurement for both inside and outside environment in the centre.

\subsection{Methodology}

The methodology for data collection involved site visit, personal observations, photograph documentation and interviews with the interventionists.

Researchers explore the specific spatial and sensory needs associated with autism and photographs taken to analyse existing conditions. While visiting the site, we had an open ended interview with consultant architect and interventionist. Both of them briefing and guiding us throughout the site visit.

Design Criteria Check (DCC) List is part of benchmarking tool assisted in identifying the design criteria in autism centre. It identified a design through a series of statements which encompassed the four areas - physical building, internal environment, sensory issues and sensory space.

The physical building dealt with building entrance, building scale, safety \& security. The internal environment dealt with personal space and movement, wayfinding, legibility, threshold, classroom, toilet, windows, playroom and quiet room. The sensory issues dealt with visual distraction, sun \& glare, lighting, acoustics, smell and colour. Lastly, the sensory space dealt with calm low stimulus spaces, engaging with others and safety and security.

\subsection{Procedure}

Prior to the site visit for data collection, researcher had an opportunity to visit PPK with Persatuan Arkitek Malaysia (PAM) during their academic visit. Initial briefings by representatives from the consultant architect about the setup of the PPK. Consultant architect responses to the spontaneous enquiries throughout the site visits, in addition to the personal observations made with notations and photographs documented. While observing the environment, the visits were concluded with filling up design criteria check list.

\subsection{Data Collection}

Research methodology has been conducted to ensure the objectives of the research can be achieved. An extensive literature review also has been carried out on the background of the research to understand the overall autistic environment. Personal observations and photographs documented were carried out to selected teachers that involved with autistic children in order to obtain the knowledge and information in details regarding the educational facilities for children with autism. Lastly, researcher requires getting classroom layout plan for further investigation.

\subsection{Limitation}

In the year 2015, the Malaysian Government has built one and only Autism Centre in Sentul, Kuala Lumpur. The scope of study involves early intervention classroom at the age of four to six years old in Pusat Permata Kurnia that facilitated by the government. Our limitation was to get approval from Autism Centre to conducting prelimanaries study and we were also adviced by the interventionist not to close to autistic children. Observation done away from the children and visiting an empty room without them. This is a challenges to us to observe the existing environment with the children occupied the classroom.

\subsection{Findings}

The result of the study highlighted factors that relating to quality physical learning environment. Based on DCC, it seems that the criterion has been taken into at early design phase.

\subsection{The Physical Building}

The case study was designed with two storey height. The larger schools can be disorientating and frightening places for autistic children. ASD children would be more tolerable and hopefully even enjoyable when their arrival to school. The entrance designed as straightforward, welcome and stress-free for them. The DCC for the physical building showed in Table 3.

Table 3. The Physical Building

\begin{tabular}{llccl} 
& PHYSICAL BUILDING & YES & NO & COMMENTS \\
& $(\sqrt{ })$ & $(X)$ & \\
\hline $1 . \quad$ Building Entrance & $\sqrt{ }$ & & $\begin{array}{l}\text { Straightforward transition } \\
\text { (stress-free as possible) }\end{array}$ \\
\hline
\end{tabular}




\begin{tabular}{|c|c|c|c|}
\hline 2. & $\begin{array}{l}\text { Scale and Organisation } \\
\text { - Classrooms grouped around a shared } \\
\text { resource base. } \\
\text { - Courtyard shared area as an } \\
\text { identifiable grouping or cluster. }\end{array}$ & $\sqrt{ }$ & $\begin{array}{l}2 \text { storey height institutional } \\
\text { building. } \\
\text { (Larger schools can be } \\
\text { disorientating and frightening } \\
\text { places for autistic children.) }\end{array}$ \\
\hline 3. & Safety and Security & $\checkmark$ & $\begin{array}{l}\text { Access to and from the school is } \\
\text { secure and the children are } \\
\text { monitored at all times. }\end{array}$ \\
\hline
\end{tabular}

\subsection{Internal Environment}

The internal environment has been designed to comprehend the ASD child impartment. The overall findings for internal environment tabulated in Table 4.

Table 4. The Internal Environment

\begin{tabular}{|c|c|c|c|c|}
\hline & INTERNAL ENVIRONMENT & $\begin{array}{l}\text { YES } \\
(\sqrt{ })\end{array}$ & $\begin{array}{l}\text { NO } \\
(X)\end{array}$ & COMMENTS \\
\hline 4. & Personal space and movement & $\sqrt{ }$ & & $\begin{array}{l}\text { Allowing extra space for circulation } \\
\text { can give the child with ASD more } \\
\text { comfortable distance from his/her } \\
\text { peers. }\end{array}$ \\
\hline 5. & $\begin{array}{l}\text { Wayfinding } \\
\text { - } \quad \text { Complex layouts } \\
\text { - } \quad \text { Frequent changes of level }\end{array}$ & $\sqrt{ }$ & $\begin{array}{l}x \\
x\end{array}$ & $\begin{array}{l}\text { The circulation around the school } \\
\text { is clear and comprehensible as } \\
\text { possible. }\end{array}$ \\
\hline 6. & Legibility & $\sqrt{ }$ & & $\begin{array}{l}\text { Personalising rooms using } \\
\text { individual colours or objects can } \\
\text { facilitate association for autistic } \\
\text { children. }\end{array}$ \\
\hline 7. & Threshold & $\sqrt{ }$ & & $\begin{array}{l}\text { A seated space within the } \\
\text { classroom or in the form of a } \\
\text { recess in a corridor. }\end{array}$ \\
\hline 8. & $\begin{array}{l}\text { The Classroom } \\
\quad \text { Feel comfortable and relaxed. } \\
\text { A place of security and familiarity. } \\
\text { A safe place to seek refuge from the } \\
\text { chaos. } \\
\text { The classroom environment in order and } \\
\text { routine and the pupil should know where } \\
\text { each activity will happen and when. } \\
\text { The identification of one activity with one } \\
\text { area (zone within the classroom). } \\
\text { Illustrated by a visual timetable and } \\
\text { located in a prominent position in the } \\
\text { classroom. }\end{array}$ & $\begin{array}{l}\checkmark \\
V \\
V \\
V\end{array}$ & & $\begin{array}{l}\text { The choice of colours, textures } \\
\text { and materials are carefully } \\
\text { selected physiologically, } \\
\text { psychologically and } \\
\text { therapeutically. }\end{array}$ \\
\hline 9. & \begin{tabular}{ll}
\multicolumn{2}{l}{ Toilet } \\
- & Ergomonic \\
- & Sound \\
- & Smell
\end{tabular} & $\begin{array}{l}\sqrt{ } \\
\sqrt{ } \\
\sqrt{ }\end{array}$ & & $\begin{array}{l}\text { Toilets \& pantries are an absolute } \\
\text { necessity not only as part of toilet } \\
\text { training program but also the living } \\
\text { skill program. }\end{array}$ \\
\hline 10. & Windows & $\sqrt{ }$ & & $\begin{array}{l}\text { Provision of blinds to windows in } \\
\text { order to minimise distraction. }\end{array}$ \\
\hline 11. & $\begin{array}{l}\text { Playroom / Activity Room } \\
\text { A classroom has access to a secure } \\
\text { external play area associated only with } \\
\text { that class or age group. } \\
\text { This area can then be linked to a larger } \\
\text { play area for the entire school population. }\end{array}$ & $\sqrt{ }$ & & $\begin{array}{l}\text { The choice of colours, textures } \\
\text { and materials are carefully } \\
\text { selected physiologically, } \\
\text { psychologically and } \\
\text { therapeutically. }\end{array}$ \\
\hline 12. & Quiet Space & $\sqrt{ }$ & & $\begin{array}{l}\text { Provision of space nearby to allow } \\
\text { the child time to calm down and in } \\
\text { effect 'recharge their batteries'. }\end{array}$ \\
\hline
\end{tabular}

\subsection{Sensory Issues.}

Designer has considered the sensory issues especially on visual distraction, sun and glare, lighting, acoustic and smell. It seems that designer has avoided bright shiny surfaces, strong texture, bright colours, bright sunlight and fluorescent lighting. The overall findings for sensory issues explained in Table 5. 
Table 5. The Sensory Issues

\begin{tabular}{|c|c|c|c|c|}
\hline & SENSORY ISSUES & $\begin{array}{l}\text { YES } \\
(\sqrt{ })\end{array}$ & $\begin{array}{l}\text { NO } \\
(X)\end{array}$ & COMMENTS \\
\hline 13. & Visual Distraction & $\sqrt{ }$ & & $\begin{array}{l}\text { The choice of colours, textures and } \\
\text { materials are carefully selected } \\
\text { physiologically, psychologically } \\
\text { and therapeutically. Bright shiny } \\
\text { surfaces, bold geometric patterns } \\
\text { and strong textures can all be } \\
\text { potential distractions. }\end{array}$ \\
\hline 14. & $\begin{array}{l}\text { Sun \& Glare } \\
\text { - Bright sunlight and glare can be disruptive } \\
\text { for any class, especially so for pupils with } \\
\text { sensory sensitivity. }\end{array}$ & $\sqrt{ }$ & & $\begin{array}{l}\text { Provision of blinds to windows in } \\
\text { order to minimise distraction. } \\
\text { Repetitive shadow and patterns are } \\
\text { avoided in this building. }\end{array}$ \\
\hline 15. & $\begin{array}{l}\text { Lighting } \\
\text { - A range of softer lighting provided to create } \\
\text { more calming environment. }\end{array}$ & $\sqrt{ }$ & & $\begin{array}{l}\text { Care has been taken when } \\
\text { choosing artificial lighting. }\end{array}$ \\
\hline 16. & Acoustics & $\sqrt{ }$ & & $\begin{array}{l}\text { Excessive noise can be } \\
\text { distracting. Care has been taken } \\
\text { when choosing material. }\end{array}$ \\
\hline 17. & Smell & $\sqrt{ }$ & & $\begin{array}{l}\text { Strong smells and even subtle } \\
\text { odours can be problematic. School } \\
\text { kitchens, dining halls, swimming } \\
\text { pools and bin areas are all } \\
\text { potentially problematic sources of } \\
\text { strong smells. }\end{array}$ \\
\hline
\end{tabular}

\subsection{Sensory Space.}

ASD children having difficulty during their meal times, PE time and break times. In PPK they allow special space for ASD children to sit and comedown so that they can familiar with their environment surrounding. Table 6 showed the findings for sensory space.

Table 6. The Sensory Space

\begin{tabular}{|c|c|c|c|c|}
\hline & SENSORY SPACE & $\begin{array}{l}\text { YES } \\
(\sqrt{ })\end{array}$ & $\begin{array}{l}\text { NO } \\
(X)\end{array}$ & COMMENTS \\
\hline 18. & $\begin{array}{l}\text { Calm low stimulus spaces } \\
\text { - ASD child love to see their work displayed. } \\
\text { But too much display may distract them. } \\
\text { All storage could be accessed directly from } \\
\text { the classroom. } \\
\text { - Low arousal colours or calming pastel shades } \\
\text { on walls, floors and ceilings. }\end{array}$ & $\begin{array}{l}\sqrt{ } \\
\sqrt{ }\end{array}$ & & $\begin{array}{l}\text { Interventionist determined what \& } \\
\text { how much to display. } \\
\text { Care has been taken when choosing } \\
\text { colours. }\end{array}$ \\
\hline 19. & $\begin{array}{l}\text { Engaging with others } \\
\text { - Provision of respite places, where children } \\
\text { can rest or pause momentarily to collect } \\
\text { themselves, can be beneficial. }\end{array}$ & $\sqrt{ }$ & & $\begin{array}{l}\text { A rest space provided with a safe } \\
\text { location from where the pupil can } \\
\text { watch the others without being } \\
\text { completely removed from their } \\
\text { activity. Similarly a recess with } \\
\text { seating along a corridor or } \\
\text { circulation area can provide a refuge } \\
\text { for pause or rest. }\end{array}$ \\
\hline 20. & $\begin{array}{l}\text { Safety and Security } \\
\text { - Any escape path from the classroom to } \\
\text { exterior is hampered by the action of at least } \\
\text { two doorways }\end{array}$ & $\sqrt{ }$ & & $\begin{array}{l}\text { Provided to ensure the safety for } \\
\text { ASD child. }\end{array}$ \\
\hline 21. & Garden & $\sqrt{ }$ & & Sensory garden provided. \\
\hline
\end{tabular}

\subsection{Conclusion}

Our exploration on the impact of sensory design on autistic behaviour as in Table 2 showed that the needs is important to designed physical learning environment to meet students' basic needs through acoustic, colour, smell, lighting, accessibility, wayfinding, compartmentation, scale of the building, quiet room, safety, garden and alternative. However, the findings from the present research as in Table 3, Table 4, Table 5 and Table 6 signify the importance of paying attention to physical learning environment in terms of sensory design such as physical building, internal environment, sensory issues and sensory space. In particular, by paying attention to the sensory design it is hope that the physical learning environment would give less impact to autistic behavior. Hence, the result showed that most of the criteria have been considered by architect and designer and perhaps for future research is needed to measure on conduciveness of autism centre base on design criteria check list. However, the measurement would be more specific using 'Likert scale'. Creating conducive learning environment not only optimises the classroom environment but also upon parent's and teacher's 
satisfaction. Hence, this research could contribute towards the creation of a quality environment and to ensure the conducive and quality of the physical learning environment that accommodate the needs of autistic children within the Malaysian context.

\section{Acknowledgement}

I would like to thank to my supervisor Dr. Siti Rasidah Md Sakip and Asso. Prof. Dr. Ismail Samsuddin for supporting me. In addition, I would thank to Jabatan Kerja Raya Malaysia for giving me opportunity to further my study.

\section{References}

Altenmüller-Lewis, U. (2017). Designing Schools for Students on the Spectrum. The Design Journal, 20(sup1), S2215-S2229. https://doi.org/10.1080/14606925.2017.1352738

Amirul, N. J., Nidzam, C., Ahmad, C., Yahya, A., Faizal, M., Abdullah, N. L., ... Noh, N. M. (2013). The physical classroom learning environment, (2nd International Higher Education Teaching and Learning Conference 2013), 9 pages.

Arnaiz, P., Segado, F., \& Albaladejo, L. (2011). Autism and the Built Environment. Autism Spectrum Disorders - From Genes to Environment, 363-380. https://doi.org/10.5772/20200

Barker, K. (2014). Sensory Design For Autism. Retrieved December 18, 2017, from http://justlivinginteriors.co.uk/sensory-design-autism/

Beaver, C. (n.d.). Education and Therapies. Autism-Friendly Environments. Education and Therapies. Retrieved from https://www.scribd.com/document/137340850/Christopher-Beaver-the-Autism-File-Autism-Friendly-Environments-20101.

Beaver, C. (2011). Designing Environments for Children \& Adults with ASD. Ga Architects.

Boyce, P., Hunter, C., \& Howlett, O. (2003). The Benefits of Daylight through Windows. Lighting Reasearch Center, 1(1), 1-88. https://doi.org/12180-3352 Chiam, M. (2016, April 18). Stepping Up. The Star.

Cikili, Y., Sari, H., \& Deniz, S. (2015). The Evaluation of the Qualifications of Teachers Working with Students with Autism in Turkey in Terms of Views of Teachers and Parents. In ICBTS (Ed.), The 2015 International Academic Research Conference (pp. 118-208). UK: University of London.

Creswell, J. W. (2003). Creswell, J.W. (2003). One, "A Framework for Design." Research Design Qualitative Quantitative and Mixed Methods Approaches, 3-26. https://doi.org/10.3109/08941939.2012.723954

Ghazali, R., Md Sakip, S. R., \& Samsuddin, I. (2018). A Review of Sensory Design Physical Learning Environment for Autism Centre. E-IPH, AicQoL2018Perhentian/sland, 3(7), 7 pages.

Goodyear, S. (2014). Designing Buildings for Children With Autism. Retrieved May 15, 2018, from https://www.citylab.com/design/2014/04/designing-buildings-childrenautism/8960/

Hamzah, Z. (2016). 12,785 golongan autisme berdaftar dengan JKM. Utusan Malaysia. Retrieved from http://www.utusan.com.my/berita/wilayah/12-785-golonganautisme-berdaftar-dengan-jkm-1.219119\#ixzz51T8GDinq, retrieved 12 January 2018

Henshall, C. (2008). Unusual sensory experiences in people on the autism spectrum. Thesis. The University of Warwick. Retrieved from http://webcat.warwick.ac.uk/record=b2247749 S1

Kinnealey, M., Pfeiffer, B., Miller, J., Roan, C., Shoener, R., \& Ellner, M. L. (2012). Effect of classroom modification on attention and engagement of students with autism or dyspraxia. American Journal of Occupational Therapy, 66(5), 511-519. https://doi.org/10.5014/ajot.2012.004010

Lingle, J. (n.d.). Creating a Sensory Space for Your Students. Autism Educates. Retrieved from www.AutismEducates.com

Matin, N., Phd, S., Allah, H., Phd, H., Ali, S., Phd, S., ... Phd, H. H. A. (2017). The Impact of Dynamic Seating on Classroom Behavior of Students with Autism Spectrum Disorder. 29 Iran J Child Neurol. WINTER Iran J Child Neurol. Winter, 11(111), 29-36. Retrieved from https://www.ncbi.nlm.nih.gov/pmc/articles/PMC5329757/pdf/ijcn11-029.pdf

Mcnally, H., Morris, D., \& Mcallister, K. (2013). Experiencing Primary School through the lens of the autistic spectrum. Aldo goes to Primary School. Mostafa, M. (2014). Architecture for autism: Autism aspectss??? in school design. Archnet-IJAR.

Nazri, N. A., \& Ismail, Z. (2016). Educational building facilities for children with autism in Malaysia. Jurnal Teknologi. https://doi.org/10.11113/jt.v78.8489

Paron-Wildes, A. J. (2005). Sensory Stimulation and Autistic Children. Implications, 06(04), 1-5.

Phillips, J., Minjarez, M., Mercier, E., Feinstein, C., \& Hardan, A. Y. (2011). Autism spectrum disorders. Handbook of Developmental Psychiatry, 66(5), 463-490. https://doi.org/10.4324/9781315283531

Samadi, S. A., \& McConkey, R. (2011). Autism in Developing Countries: Lessons from Iran. Autism Research and Treatment, 2011(August), 1-11. https://doi.org/10.1155/2011/145359

Scott, I. (2009). Designing learning spaces for children on the autism spectrum. Good Autism Practices, (10)1(May 2009), 36-51.

Shaari, M. F., \& Ahmad, S. S. (2016). Physical Learning Environment: Impact on Children School Readiness in Malaysian Preschools. Procedia - Social and Behavioral Sciences, 222, 9-18. https://doi.org/10.1016/j.sbspro.2016.05.164 
Society, T. N. A. (2015). Autism Friendly Design. Your Autism Magazine, 49(2), 513600-513600. Retrieved from http://www.autism.org.uk/professionals/others/architects/autism-friendly-design.aspx

The National Autistic Society. (2015). Autism-friendly design. The National Autistic Society, 49(2). Retrieved from http://www.autism.org.uk/professionals/others/architects/autism-friendly-design.aspx

Vogel, C. L. (2008). Classroom Design for Living and Learning with Autism. Autism Asperger's Digest, 10 pages.

Woronko, D., \& Killoran, I. (2011). Creating Inclusive Environments for Children with Autism. Autism Spectrum Disorders - From Genes to Environment, 213-226. Yates, M., Mclaren, B., \& Proksch, G. (2016). Building Better Schools: A New Model For Autism Inclusion in Seattle.

Yeo, K. J., \& Teng, K. Y. (2015). Social skills deficits in autism: a study among students with autism spectrum disorder in inclusive classrooms. Universal Journal of Educational Research, 3(12), 1001-1007. https://doi.org/10.13189/ujer.2015.031208 